\title{
Biosphere 2 begins fight for credibility
}

Oracle, Arizona. Columbia University is planning to use a modest programme of carefully-controlled experiments in biogeochemistry and plant physiology to rebuild the scientific credibility of the Biosphere 2 complex, for which the New Yorkbased university assumed full management responsibility at the beginning of the year.

The programme will mark the end of efforts to use Biosphere 2 to replicate an ecosystem parallel to that of planet Earth. Instead, scientists using the facility will pursue a more prosaic goal, namely the conduct of properly controlled experiments on a par with others already taking place in ordinary greenhouses around the world.

Plans to prepare such a research programme were endorsed by an informal panel of two dozen external scientists brought together by Wally

Broecker, professor of geology at Desert vision: no longer just a curiosity.

Columbia's Lamont-Doherty Earth

Observatory (LDEO), at meetings held at

Biosphere 2 two weeks ago.

But many panel members continued to express scepticism about how useful the giant, fully-enclosed greenhouse is likely to be for scientific research. As an ecosystem, it bears no obvious relation to the outside world. Its soil is unusual, its lighting blocked by the over-engineered structure is poor, and there is no wildlife except for ants and cockroaches.

Furthermore the ability to 'close' the system is incomplete, and of limited scientific value. As a greenhouse, the Biosphere is dark and expensive to run. Indeed its very uniqueness makes replication difficult.

Nevertheless, according to Bruno Marino, the facility's chief scientist, Biosphere 2 presents "a fantastic opportunity to look at the pattern of response of different plants to shared environmental conditions". Most panel members agreed that, given sufficient determination and imagination, a way can be found to do good research there.

"The Biosphere was not built to do science, and its conversion is going to be tricky," concedes Broecker, the man behind a deal which Columbia has struck with Ed Bass, the Texan billionaire, to run the complex at his expense for the next five years (see Nature 378, 223; 1995). Bass had previously spent up to $\$ 150$ million building the complex, which was used in two notoriously failed attempts to enable humans ('Biospherians') to survive in complete isolation from planet Earth ('Biosphere 1').

The panel considered, in essence, two opinions of how the complex should develop. Broecker wants to use it for simple, quantifiable experiments, such as comparing the progress of plants at two different carbon dioxide levels. Biosphere ecologist Tony Burgess, however, advocates a qualitative programme, closer to Biosphere's original concept, to study biodiversity in a self-contained ecosystem.

The ecologists think that the complex can serve as a model for the human-controlled ecosystems of the future. Biosphere's problem of managing a small, artificially constrained ecosystem "is exactly the problem that is facing every director of every wildlife reserve in the world," says Burgess.

\section{IMAGE UNAVAILABLE FOR COPYRIGHT REASONS}

But Broecker says that he cannot see how the ecologists would use the Biosphere to yield novel scientific information. "You're not really saying how you're going to use that ecosystem to solve any important problem," he told the ecologists. Broecker has a major problem of his own in mind, namely the increase in carbon dioxide in the atmosphere, and the study of its impact on plants. "Our thrust is to utilize Biosphere 2 in that quest," he says.

Work is already under way on this topic. Guanghui Lin, a researcher at Biosphere 2, has already used the carbon dioxide buildup there - caused by the compost-like soil - to monitor the responses of different types of plant.

The panel endorsed Broecker's approach. But the layout of Biosphere 2 will still allow some ecological work to be done. The tee-shaped greenhouse consists of two

chambers: the "wilderness" chamber and the "agriculture" chamber where the Biospherians used to try to grow their food.

Under the $\$ 150,000$ plan endorsed by last week's panel, the agriculture chamber will be split into three sections this summer. The separation will be by polythene sheeting: solid glass walls would be expensive, lightreducing, and vulnerable to pressure gradients. As a result, scientists such as Lin will be able to run proper control experiments, improving their chances of having their results published.

The panel also suggested that the agriculture area - much of which is now full of wheat should grow some kind of tropical agroforest system, such as coffee and inga, which would take advantage of the greenhouse's height.

The wilderness area will continue to attract the interest of tourists. But its future as a research tool is as murky as its artificial ocean, algaefilled and bereft of other life. "I was disappointed that there were no really crisp ideas" for biodiversity research in the area, says Broecker.

Columbia will review its participation after three years, according to John Mutter, interim director of LDEO. "We fully expect to be here beyond five years," he says, adding that the objective is to break even in that time.

Tourist income already covers $\$ 2$ million of the complex's $\$ 6$ millionannual running costs. Columbia expects to make up the rest chiefly through educational programmes, starting this year with a summer camp and a fall semester for paying undergraduates.

Research will underpin this intellectually, but not financially: Biosphere 2 will not attract a huge amount of outside money, says Mutter.

Colin Macilwain

\section{Mandela backs role of academy}

Cape Town. South African President Nelson Mandela has challenged the country's newly-formed Academy of Science to inspire the country's youth to seek careers in science, engineering and technology.

Addressing the inaugural dinner of the academy in Pretoria last Friday, Mandela described as "immense" South Africa's need for rapid expansion of its scientific and technological skills. "None of us need to be persuaded of the utility of science to national growth and prosperity," declared Mandela. He emphasized that the academy had the potential to play a critical role in the development of both science and the nation as a whole.

In particular, Mandela invited the academy to comment on the draft white paper on science and technology, which is due to be released during the course of the current parliamentary session. He also asked the academy to back closer cooperation between South African scientists and other African scientists, in order to share the former's skills and technology with the rest of the continent.

The new academy has elected Khotso Mokhele, a microbiologist who is the president-elect of the country's main funding agency for research, the Foundation for Research Development, as its first president. Jennifer Thomson, of the University of Cape Town, and Njabulo Ndebele, vicechancellor of the University of the North, have been elected as vice-presidents, and William Makgoba, of the University of the Witwatersrand as general secretary.

Michael Cherry 